SANTOS, KC; KAWAKAMI, J; GENÚ, AM; PASSOS, S; ESCHEMBACK, V. 2018. New national potato genotypes: yield response to different doses of 4-14-8 NPK fertilizer. Horticultura Brasileira 36: 106-111. DOI - http://dx.doi.org/10.1590/S0102-053620180118

\title{
New national potato genotypes: yield response to different doses of 4-14-8 NPK fertilizer
}

\author{
Keli Cristina Santos; Jackson Kawakami; Aline M Genú; Sara Passos; Vlandiney Eschemback \\ Universidade Estadual do Centro-Oeste (UNICENTRO), Guarapuava-PR, Brazil; santtos_keli@yahoo.com.br; jkawakami@unicentro.br; \\ agenu@unicentro.br; sarapassos84@gmail.com; vlandiney@hotmail.com
}

\begin{abstract}
The fertilization of potato crops generally does not take into account the genotype, although genotypes may respond differently to fertilization. This study aimed to determine the yield of new potato genotypes (cultivar BRS Camila and clone CL 02-05), as well as the cultivar Ágata, submitted to four NPK 4-14-8 fertilizer doses ( 0 , 2, 4 and $6 \mathrm{t} \mathrm{ha}^{-1}$ ) in the crop seasons of 2013/14 and 2014/15. We evaluated the total and marketable tuber yield, total and marketable tuber number, percentage of marketable tuber dry weight, average marketable tuber weight and plant growth period. The experimental design was randomized blocks in split plot scheme, with fertilizer doses allocated as main plots and genotypes as subplots, with three replications. We did not observe significant interaction for any analyzed variable. The clone CL 02-05 showed higher total and marketable tuber yield compared to the other cultivars, mainly due to its higher production of tuber number. However, we observed a high amount of tubers not suited for commercialization from the clone CL 02-05. Cultivar BRS Camila produced fewer marketable tubers than cultivar Ágata in crop season 2014/15, but without difference in marketable yield. On the other hand, plants of cultivar BRS Camila had a longer growth period of 7 days and the tubers of this cultivar accumulated higher percentage of dry weight compared to cultivar Ágata. The new tested genotypes had yield response similar to cultivar Ágata when submitted to doses of 4-14-8 NPK fertilizer. Therefore, the fertilization management of these new genotypes may be similar to that used with cultivar Ágata.
\end{abstract}

Keywords: Solanum tuberosum, clone, cultivar, fertilization, productivity, variety.

\section{RESUMO}

Novos genótipos nacionais de batata: resposta produtiva a doses de fertilizante NPK 4-14-8

A fertilização da cultura da batata geralmente não leva em consideração o genótipo, apesar dos genótipos poderem responder de forma diferente à fertilização. Este trabalho objetivou quantificar a produtividade de novos genótipos (cultivar BRS Camila e clone CL 02-05) de batata, além da cultivar Ágata, submetidos a quatro doses de fertilizante NPK 4-14-8 (0, 2, 4 e 6 tha $\left.^{-1}\right)$ nos anos agrícolas de 2013/14 e 2014/15. Avaliou-se a produtividade total e comercial, número de tubérculo total e comercial, porcentagem de massa seca e massa média de tubérculo comercial e período de crescimento. $\mathrm{O}$ delineamento experimental foi de blocos ao acaso com parcelas subdivididas, sendo as doses de fertilizantes alocadas na parcela e os genótipos na subparcela, com três repetições. Nenhuma variável analisada apresentou interação significativa. O clone CL 02-05 apresentou maior produtividade comercial e total que as demais cultivares, principalmente devido ao maior número de tubérculos produzidos. Entretanto observou-se alta quantidade de tubérculos fora do padrão comercial no clone CL 02-05. A cultivar BRS Camila produziu menos tubérculos comerciais que a cultivar Ágata no ano agrícola de 2014/15, porém sem diferença na produtividade comercial. Por outro lado, as plantas da cultivar BRS Camila foram 7 dias mais longevas e os tubérculos dessa cultivar acumularam maior porcentagem de massa seca que a cultivar Ágata. Os novos genótipos testados responderam em produtividade de forma similar à cultivar Ágata quando submetidos a doses de fertilizante NPK 4-14-8. Dessa forma, o manejo da fertilização desses novos genótipos pode ser realizado de forma análoga à da cultivar Ágata.

Palavras-chave: Solanum tuberosum, adubo, clone, cultivar, rendimento, variedade.

Received on July 6, 2016; accepted on August 30, 2017

$\mathrm{P}_{\mathrm{i}}^{\mathrm{o}}$ otato (Solanum tuberosum) crop is frequently managed with high quantities of fertilizer, disregard of the contents of elements in the soil. Fertilizers can account for up to $20 \%$ of the total cost of a potato crop, and along with tuber seeds, usually represent the highest costs of production of this crop in Brazil (Deleo, 2015). Fertilizer excess may result in negative impacts to crop management. In studies with potassium dosage and yield of potato plants, the crop is receiving potassium doses beyond necessity on soils with high quantity of this element (Kang et al., 2014). Furthermore, there are reports of negative impacts of fertilizer excess on the environment. A nitrogen lixiviation potential to underground waters of up to $180 \mathrm{~kg} \mathrm{ha}^{-1}$ has been observed on areas of sandy soils in USA (Shrestha et al., 2010), as well as an eutrophication potential of water by the excess fertilization with phosphorus along with irrigation on potato crop (Chien et al., 2011). Since on potato crops the soil inversion for planting is intense, in conjunction with doses of up to $600 \mathrm{~kg} \mathrm{ha}^{-1}$ of $\mathrm{P}_{2} \mathrm{O}_{5}$, the risk of phosphorus lixiviation to rivers and 
lakes is not negligible.

The excess of fertilizer may increase the soluble sugar contents in potato, leading to an increase in the damage caused by Agrotis ipsilon (Lepidoptera, Noctuidae) on tubers and stems (Azeredo et al., 2004). Likewise, the increase in nitrogen may increase the incidence of Phytophthora infestans on the leaves of the plants (Bangemann et al., 2014). Moreover, the utilization of doses higher than the optimum dose carries negative consequences to the quality of tubers. There are studies reporting that the increase in nitrogen (Kawakami, 2015) and potassium fertilization (Laboski \& Kelling, 2007) result in lower percentage of tuber dry weight, a negative characteristic in the evaluation of tuber quality destined to industry. On the other hand, studies verified that on soils of low phosphorus availability, phosphate fertilization increases starch content (Fernandes et al., 2015) or specific gravity (Laboski \& Kelling, 2007) of tubers.

The national potato production chain majorly uses cultivars bred outside the country. However, the study of yield potential of foreign and national genotypes on the south of Minas Gerais State (MG), Brazil, concluded that national genotypes have higher yield potential than foreign cultivars (Carmo et al., 2009). Similar results were found in studies conducted on the south of MG (Pinto et al., 2010), in BrasíliaDF (Eschemback et al., 2014), and in Pelotas-RS (Silva et al., 2012).

Recently, new potato cultivars have been released by Brazilian breeding programs (Pereira et al., 2013, 2015a), being BRS F63 (Camila) one of the most recent, released in 2015 (Pereira et al., 2015b). In spite of the cultivars having different needs of both macronutrients (Fernandes et al., 2011) and micronutrients (Soratto et al., 2011), few are the works which test the effect of different fertilizer doses on these new cultivars. Still, growers generally manage the fertilization of new cultivars in the same way that was done with foreign cultivars, fact that may difficult the adoption of national cultivars.

The aim of this study was to evaluate the yield response of cultivar BRS
Camila and clone CL 02-05 submitted to different doses of 4-14-8 NPK fertilizer, using cultivar Ágata as control.

\section{MATERIAL AND METHODS}

The experiment was held in the crop seasons of 2013/14 and 2014/15 in Guarapuava-PR. In the crop season of 2013/14, the experiment was held on a commercial production area at Lageado Grande Farm, Palmeirinha district $\left(25^{\circ} 18^{\prime} 23^{\prime} \mathrm{S}, 51^{\circ} 36^{\prime} 40^{\prime \prime} \mathrm{W}\right)$, in the period from December 2013 to April 2014. In crop season 2014/15, the experiment was held at the experimental field of Midwestern State University,

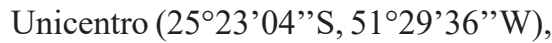
in the period from October 2014 to February 2015.

The soil, on both locations, is classified as very clayey Typic Hapludox according to Soil Taxonomy (Soil Survey Staff, 2014) or Latossolo Bruno distrófico, based on the Brazilian Soil classification system (Embrapa, 2013), and presented the following chemical characteristics at the depth of $0-20 \mathrm{~cm}$ : $\mathrm{pH}\left(\mathrm{CalCl}_{2}\right)=4.8$ and $4.8 ; \mathrm{P}($ Mehlich $)=$ 2.4 and $2.3 \mathrm{mg} \mathrm{dm}^{-3} ; \mathrm{K}=0.4$ and 0.2 $\mathrm{cmol} \mathrm{dm}^{-3} ; \mathrm{Ca}=1.8$ and $3.5 \mathrm{cmol}_{\mathrm{c}}$ $\mathrm{dm}^{-3} ; \mathrm{Mg}=1.8$ and $1.8 \mathrm{cmol}_{\mathrm{c}} \mathrm{dm}^{-3}$; $\mathrm{Al}=0.0$ and $0.0 \mathrm{cmol}_{\mathrm{c}} \mathrm{dm}^{-3} ; \mathrm{H}+\mathrm{Al}=$ 5.2 and $6.0 \mathrm{cmol} \mathrm{dm}^{-3} ; \mathrm{SB}=4.0$ and $5.5 \mathrm{cmol}_{\mathrm{c}} \mathrm{dm}^{-3} ; \stackrel{c}{\mathrm{C}} \mathrm{EC}=9.20$ and 11.6 $\mathrm{cmol}_{\mathrm{c}} \mathrm{dm}^{-3}$ and base saturation $(\mathrm{V} \%)=$ 44 and 48, respectively for Lageado Grande farm and the experimental field of Midwestern State University. Based on these results, the necessary amount of limestone was calculated and applied three months before soil preparation, in both crop seasons.

Soil preparation begun around a month prior to the implantation of the crop, with one subsoiling and two harrowings, and further furrowing of the area, in both crop seasons. In crop season 2013/14 the planting of tubers was held on December 7, 2013, and the hilling was done 15 days after emergence (DAE). In crop season 2014/15, planting was held on October 4, 2014, and the hilling was done 18 DAE. Phytosanitary management was done according to usual practices of the region for the crop, and no irrigation was held on either crop seasons.

Treatments consisted of three potato genotypes: cultivar Ágata, cultivar BRS F63 (BRS Camila) and clone CL 02-05; and four doses of 4-14-8 NPK fertilizer with boron $(0.03 \%)$ : $0 ; 2 ; 4$ and $6 \mathrm{t} \mathrm{ha}^{-1}$. Seed tubers from cultivar Ágata were obtained from a regional seed tuber producer, while seed tubers from cultivar BRS Camila and clone CL 02-05 were obtained from Embrapa Produtos e Mercado, Canoinhas office. In the second crop season seed tubers produced in the first crop season were used, but only the cultivars Ágata and BRS Camila were used. Experimental design was a completely randomized block, in a split-plots scheme, with doses assigned to the main plots and cultivars to the subplots, with three replicates, in both crop seasons.

Each subplot measured $3 \times 4.8 \mathrm{~m}$, composed by six rows, with ten plants in each row, in a spacing of $0.80 \mathrm{~m}$ between rows and $0.30 \mathrm{~m}$ between plants, in crop season 2013/14. In crop season 2014/15, 12 plants per row were used, in a spacing of $0.80 \mathrm{~m}$ between rows and $0.25 \mathrm{~m}$ between plants. The NPK fertilizer was distributed in total dose in the furrow immediately before manual planting of tubers, in both crop seasons.

Yield quantification was held at 117 and 127 days after planting in the crop seasons of 2013/14 and 2014/15, respectively, by collecting 12 plants per plot, from the four central rows, leaving at least one of the outermost plants as border. Tubers were harvested, washed and classified as total and marketable tubers ( $>45 \mathrm{~mm}$ diameter). The number and fresh weight (FW) of total and marketable tubers and the dry weight (DW), percentage of DW and average $\mathrm{FW}$ (FW/number) of marketable tubers were quantified in both crop seasons. Dry weight of tubers was estimated after drying them in a forced air heater at $70^{\circ} \mathrm{C}$ until constant weight.

Growth period (cycle) was estimated only in crop season $2014 / 15$ by the difference in days between the date at which $75 \%$ of the plot's plants had emerged and the date at which $75 \%$ of the plot's plants showed yellowed leaves (senescence). Quantification was done by visual evaluations held each 
two or three days from the beginning of emergence and yellowing of leaves.

Analysis of variance, Tukey test and regression for doses of NPK were held in the program SISVAR. The linear and quadratic regression models were considered between the doses and the assessed characteristic, being the criteria for choosing the regression model the significant equation $(5 \%)$ that resulted on the higher determination coefficient $\left(\mathrm{R}^{2}\right)$. On the quadratic equations, the maximum or minimum point (abscissa) was calculated equalling the ordinated (y) to zero, deriving it and solving the equation.

\section{RESULTS AND DISCUSSION}

No significant interaction occurred between potato genotypes and fertilizer doses in none of the analysed factors in both crop seasons (Tables 1, 2 and 3 ). This result suggests that the new genotypes tested can receive fertilization analogous to what is done to cultivar Ágata if fertilizer 4-14-8 NPK is used.

Clone CL 02-05 produced a higher total tuber number than cultivars Ágata and BRS Camila in the crop season
2013/14, with no difference between cultivars Ágata and BRS Camila in both crop seasons (Table 1). A positive linear response on the production of total tuber number in response to fertilizer doses in both crop seasons was observed. Other authors also found higher total tuber number for the clone CL 02-05 than in the cultivar Ágata in Pelotas-RS (Silva et al., 2012), corroborating with the results of this experiment.

Clone CL 02-05 had highest total tuber yield in crop season 2013/14 and no difference was observed between cultivars Ágata and BRS Camila in both crop seasons. A quadratic response on total tuber yield in function of fertilizer doses was observed in both crop seasons, being the fertilizer dose of maximum technical efficiency of 5.2 and $4.6 \mathrm{t} \mathrm{ha}^{-1}$ in the crop seasons of 2013/14 and $2014 / 15$, respectively.

This result corroborates previous results that verified higher yield of the clone CL 02-05 in comparison to the cultivar Ágata (Silva et al., 2012, 2015). We highlight the yield potential of clone CL 02-05, that produced around $50 \%$ more than cultivars Ágata and BRS Camila in crop season 2013/14 (Table 1). However, clone CL 02-05 produced a large quantity of cracked tubers (non-quantified data), accounted as marketable tubers, evidencing the difficulty of allying high yield with tuber quality (Bisognin et al., 2008). On the other hand, Silva et al. (2015) observed higher total yield of the cultivar BRS Camila (clone F63-01-06) in comparison to Ágata in Pelotas-RS and Canoinhas-SC, and similar yield in Londrina-PR.

The clone CL 02-05 produced higher marketable tuber number than cultivars Ágata and BRS Camila in crop season 2013/14 and, cultivar Ágata produced higher marketable tuber number than cultivar BRS Camila in crop season 2014/15 (Table 2). Plants responded in a quadratic and linear way to fertilizer doses for the marketable tuber number in the crop seasons of 2013/14 and 2014/15, respectively. Fertilizer dose of maximum technical efficiency was of $4.8 \mathrm{t} \mathrm{ha}^{-1}$ for marketable tuber number in crop season 2013/14.

The present study corroborates data from previous studies that observed higher quantity of marketable tubers produced by clone CL 02-05 over cultivar Ágata (Silva et al., 2012, 2015). However, other authors observed higher production of marketable tubers of cultivar BRS Camila (clone F63-01-

Table 1. Total tuber number $\left(\mathrm{n}^{\mathrm{o}}\right.$ per plant) and yield $\left(\mathrm{kg} \mathrm{ha}^{-1}\right)$ of potato genotypes according to doses $\left(0,2,4,6 \mathrm{tha}^{-1}\right)$ of 4-14-8 NPK fertilizer in crop seasons 2013/14 and 2014/15. Guarapuava, UNICENTRO, 2013/14, 2014/15.

\begin{tabular}{|c|c|c|c|c|c|c|}
\hline \multirow{2}{*}{ Total tuber } & \multirow{2}{*}{ Crop season } & \multicolumn{3}{|c|}{ Genotypes (G) } & \multirow{2}{*}{ Anova } & \multirow{2}{*}{ CV1 $(\%)^{4}$} \\
\hline & & Agata & Camila & $02-05$ & & \\
\hline \multirow{2}{*}{ Number per plant } & $2013 / 2014$ & $7.47 b^{1}$ & $7.67 \mathrm{~b}$ & $9.89 a$ & $* * 3$ & 17.9 \\
\hline & $2014 / 2015$ & 5.8 & 4.91 & -2 & ns & 21.3 \\
\hline \multirow{4}{*}{ Yield $\left(\mathrm{kg} \mathrm{ha}^{-1}\right)$} & $2013 / 2014$ & $25,432 \mathrm{~b}$ & $29,780 \mathrm{~b}$ & $43,414 a$ & $* *$ & 13.4 \\
\hline & $2014 / 2015$ & 42,207 & 41,055 & - & ns & 20.4 \\
\hline & & \multicolumn{4}{|c|}{ Fertilizer doses $\left(\mathrm{t} \mathrm{ha}^{-1} ; \mathrm{D}\right)$} & \multirow{2}{*}{ CV2 (\%) } \\
\hline & & $\mathbf{0}$ & 2 & 4 & 6 & \\
\hline \multirow{2}{*}{ Number per plant } & $2013 / 2014$ & 6.16 & 8.69 & 8.62 & 9.9 & 16.7 \\
\hline & $2014 / 2015$ & 3.88 & 5.68 & 5.94 & 5.92 & 18.8 \\
\hline \multirow{3}{*}{ Yield $\left(\mathrm{kg} \mathrm{ha}^{-1}\right)$} & $2013 / 2014$ & 21,286 & 33,532 & 37,523 & 39,161 & 14.1 \\
\hline & $2014 / 2015$ & 25,800 & 42,691 & 49,678 & 48,356 & 17.3 \\
\hline & & \multicolumn{3}{|c|}{ Regression } & $\mathbf{R}^{2}$ & G x D \\
\hline \multirow{2}{*}{ Number per plant } & $2013 / 2014$ & \multicolumn{3}{|c|}{$Y=6.67+0.56 x$} & $0.84 * *$ & $\mathrm{~ns}$ \\
\hline & $2014 / 2015$ & \multicolumn{3}{|c|}{$\mathrm{Y}=4.40+0.32 \mathrm{x}$} & $0.69 *$ & ns \\
\hline \multirow{2}{*}{ Yield $\left(\mathrm{kg} \mathrm{ha}^{-1}\right)$} & $2013 / 2014$ & \multirow{2}{*}{\multicolumn{3}{|c|}{$\begin{array}{c}Y=21,581+6,858 x-662.9 x^{2} \\
Y=25,880+10,563 x-1,138 x^{2}\end{array}$}} & $0.99^{*}$ & ns \\
\hline & $2014 / 2015$ & & & & $0.99 *$ & $\mathrm{~ns}$ \\
\hline
\end{tabular}

${ }^{1}$ Different letters show difference among genotypes in the crop season (Tukey, $5 \%$ ). ${ }^{2}$ In the second crop season the clone CL $02-05$ was not used in the experiment. ${ }^{3 *}, * *$ and ns represent statistical difference at $5 \%, 1 \%$ of probability, and no significant difference, respectively. ${ }^{4} \mathrm{CV} 1$ and $\mathrm{CV} 2$ indicate the coefficient of variation of the plot and subplot, respectively. 
Table 2. Number of marketable tubers ( $\mathrm{n}^{\mathrm{o}}$ per plant) and marketable yield $\left(\mathrm{kg} \mathrm{ha}^{-1}\right)$ of potato genotypes according to doses $\left(0,2,4,6 \mathrm{t}\right.$ ha $\left.{ }^{-1}\right)$ of 4-14-8 fertilizer NPK in crop seasons 2013/14 and 2014/15. Guarapuava, UNICENTRO, 2013/14, 2014/15.

\begin{tabular}{|c|c|c|c|c|c|c|}
\hline \multirow{2}{*}{ Marketable tuber } & \multirow{2}{*}{ Crop season } & \multicolumn{3}{|c|}{ Genotypes (G) } & \multirow{2}{*}{ Anova } & \multirow{2}{*}{ CV1 (\%) } \\
\hline & & Agata & Camila & $02-05$ & & \\
\hline \multirow{2}{*}{ Number per plant } & $2013 / 2014$ & $5.64 b^{1}$ & $5.40 \mathrm{~b}$ & $7.12 \mathrm{a}$ & $* * 3$ & 17.1 \\
\hline & $2014 / 2015$ & 5.26 & 4.43 & -2 & $*$ & 23.0 \\
\hline \multirow{4}{*}{ Yield $\left(\mathrm{kg} \mathrm{ha}^{-1}\right)$} & $2013 / 2014$ & $22,763 b$ & $27,325 \mathrm{~b}$ & $40,054 \mathrm{a}$ & $* *$ & 13.3 \\
\hline & $2014 / 2015$ & 41,248 & 40,299 & - & ns & 21.0 \\
\hline & & \multicolumn{4}{|c|}{ Fertilizer doses $\left(\mathrm{t} \mathrm{ha}^{-1} ; \mathrm{D}\right)$} & \multirow{2}{*}{ CV2 (\%) } \\
\hline & & $\mathbf{0}$ & 2 & 4 & 6 & \\
\hline \multirow{2}{*}{ Number per plant } & $2013 / 2014$ & 4.15 & 6.63 & 6.45 & 6.96 & 15.5 \\
\hline & $2014 / 2015$ & 3.53 & 5.19 & 5.43 & 5.22 & 17.9 \\
\hline \multirow{3}{*}{ Yield $\left(\mathrm{kg} \mathrm{ha}^{-1}\right)$} & $2013 / 2014$ & 18,776 & 30,880 & 34,716 & 35,817 & 14.1 \\
\hline & $2014 / 2015$ & 25,255 & 41,852 & 48,778 & 47,208 & 17.3 \\
\hline & & \multicolumn{3}{|c|}{ Regression } & $\mathbf{R}^{2}$ & GxD \\
\hline \multirow{2}{*}{ Number per plant } & $2013 / 2014$ & \multicolumn{3}{|c|}{$\mathrm{Y}=4.32+1.15 \mathrm{x}-0.12 \mathrm{x}^{2}$} & $0.89 *$ & ns \\
\hline & $2014 / 2015$ & \multicolumn{3}{|c|}{$\mathrm{Y}=4.05+0.27 \mathrm{x}$} & $0.60 *$ & ns \\
\hline \multirow{2}{*}{ Yield $\left(\mathrm{kg} \mathrm{ha}^{-1}\right)$} & $2013 / 2014$ & \multicolumn{3}{|c|}{$Y=19,053+6,874 x-687.7 \times 2$} & $0.99 * *$ & ns \\
\hline & $2014 / 2015$ & \multicolumn{3}{|c|}{$Y=25,313+10,452 x-1,135 x^{2}$} & $0.99 *$ & $\mathrm{~ns}$ \\
\hline
\end{tabular}

${ }^{1}$ Different letters show difference among genotypes in the crop season (Tukey, $5 \%$ ). ${ }^{2}$ In the second crop season the clone CL $02-05$ was not used in the experiment. ${ }^{3 *},{ }^{* *}$ and ns represent statistical difference at $5 \%, 1 \%$ of probability, and no significant difference, respectively. ${ }^{4} \mathrm{CV} 1$ and $\mathrm{CV} 2$ indicate the coefficient of variation of the plot and subplot, respectively.

06) in comparison to cultivar Ágata, disagreeing from the results of the present study (Silva et al., 2015). A study with cultivar Ágata found the dose of maximum technical efficiency of the same fertilizer for the production of marketable tubers to be $4.6 \mathrm{t} \mathrm{ha}^{-1}$ (Queiroz et al., 2013), a value close to the one found on the present study in crop season 2013/14. Other authors also observed increase on marketable tuber number in response to nitrogen dose increment (Silva et al., 2014) indicating that this nutrient plays an important role on the formation of tubers.

Clone CL 02-05 differed in marketable tuber yield from cultivars Ágata and BRS Camila with a yield approximately $37 \%$ higher than the average of these cultivars in crop season 2013/14 (Table 2). In crop season 2014/15 no difference was observed on marketable yield between cultivars Ágata and BRS Camila. Plants responded in a quadratic way to fertilizer doses to marketable tuber yield in both crop seasons, and the maximum technical efficiency was of 5.0 and $4.6 \mathrm{t}$ $\mathrm{ha}^{-1}$ in crop season 2013/14 and 2014/15, respectively.
These data corroborate with data from previous studies in which higher marketable yields of clone CL 0205 in relation to cultivar Ágata were observed (Silva et al., 2012, 2015). On the other hand, there are reports of higher marketable yield on cultivar BRS Camila (clone F63-01-06) in relation to cultivar Ágata in two out of three experiments held (Silva et al., 2015), differing from the result of the present study. Queiroz et al. (2013) observed quadratic response in marketable yield in function of the application of doses from the same formula (4-14-8 NPK) on cultivar Ágata, corroborating the type of response (quadratic) of the genotypes to the doses of this formula (Table 2).

In the crop season of 2014/15 the cycle of cultivar BRS Camila was one week longer than cultivar Ágata (Table 3). No effect of fertilizer doses was observed on the growth period of the plants. 'Ágata' was classified as a cultivar of short cycle, being used as standard and 'BRS Camila' (clone F63-01-06) was classified as being of medium cycle (Silva et al., 2015), corroborating the data of growth period found on the present study. The longer cycle of 'BRS Camila' in relation to 'Ágata' may be advantageous, since greater longevity may result in greater yield (Silva \& Pinto, 2005). On the other hand, plants that remain longer in the field encounter greater risk of facing biotic and abiotic unfavorable conditions, fact that may lead to the necessity of greater phytosanitary care, entailing higher costs for the producer.

Higher average weight of marketable tubers from cultivar BRS Camila and clone CL 02-05 in relation to 'Ágata' in crop season 2013/14 was observed. However, in the following year no difference between cultivars was observed. In both crop seasons, the increment on fertilizer dose resulted in linear increment of the average weight of tubers.

The higher marketable tuber yield of clone CL 02-05 in crop season 2013/14 (Table 2) was mainly due to the higher tuber number of this genotype, along with the high average weight of its tubers (Table 3). On the other hand, cultivar BRS Camila compensated the lower number of marketable tubers than cultivar Ágata (Table 2), producing tubers with higher average weight in 
Table 3. Growth period (days), average marketable tuber weight (g) and dry weight ( $\%)$ of potato genotypes according to doses $(0,2,4,6$ $\mathrm{t} \mathrm{ha}^{-1}$ ) of NPK 4-14-8 fertilizer in crop seasons 2013/14 and 2014/15. Guarapuava, UNICENTRO, 2013/14, 2014/15.

\begin{tabular}{|c|c|c|c|c|c|c|}
\hline \multirow{2}{*}{ Variable } & \multirow{2}{*}{ Crop season } & \multicolumn{3}{|c|}{ Genotypes (G) } & \multirow{2}{*}{ Anova } & \multirow{2}{*}{ CV1 $(\%)^{4}$} \\
\hline & & Agata & Camila & $02-05$ & & \\
\hline Growth period (days) & $2014 / 2015$ & 68 & 75 & - & $* *$ & 5.7 \\
\hline \multirow{2}{*}{ Average weight (g) } & $2013 / 2014$ & $94.8 \mathrm{~b}^{1}$ & $123 a$ & $134 \mathrm{a}$ & $* * 3$ & 9.13 \\
\hline & $2014 / 2015$ & 157 & 182 & -2 & ns & 14.1 \\
\hline \multirow{4}{*}{ Dry weight (\%) } & $2013 / 2014$ & 14.2 & $17.0 \mathrm{a}$ & $16.3 \mathrm{a}$ & $* *$ & 7.91 \\
\hline & $2014 / 2015$ & 14.4 & 16.8 & - & $*$ & 10.9 \\
\hline & & \multicolumn{4}{|c|}{ Fertilizer doses $\left(\mathrm{t} \mathrm{ha}{ }^{-1} ; \mathrm{D}\right)$} & \multirow{2}{*}{ CV2 (\%) } \\
\hline & & $\mathbf{0}$ & 2 & 4 & 6 & \\
\hline Growth period (days) & $2014 / 2015$ & 67 & 74 & 72 & 72 & 4.05 \\
\hline \multirow{2}{*}{ Average weight (g) } & $2013 / 2014$ & 108 & 111 & 128 & 122 & 10.8 \\
\hline & $2014 / 2015$ & 148 & 164 & 182 & 183 & 18.7 \\
\hline \multirow{3}{*}{ Dry weight $(\%)$} & $2013 / 2014$ & 17.5 & 15.9 & 15.5 & 14.5 & 10.1 \\
\hline & $2014 / 2015$ & 16.3 & 16.0 & 15.6 & 14.4 & 13.0 \\
\hline & & \multicolumn{3}{|c|}{ Regression } & $\mathbf{R}^{2}$ & GXD \\
\hline Growth period (days) & $2014 / 2015$ & \multicolumn{3}{|c|}{$\mathrm{Y}=71.3$} & ns & ns \\
\hline \multirow{2}{*}{ Average weight (g) } & $2013 / 2014$ & \multicolumn{3}{|c|}{$Y=108+3.00 x$} & $0.70^{* *}$ & ns \\
\hline & $2014 / 2015$ & \multicolumn{3}{|c|}{$Y=150+6.22 x$} & $0.91 *$ & ns \\
\hline \multirow{2}{*}{ Dry weight (\%) } & $2013 / 2014$ & \multicolumn{3}{|c|}{$Y=17.2-0.47 x$} & $0.94 * *$ & ns \\
\hline & $2014 / 2015$ & \multicolumn{3}{|c|}{$Y=15.6$} & ns & ns \\
\hline
\end{tabular}

${ }^{\mathrm{T}}$ Different letters show difference among genotypes in the crop season (Tukey, $5 \%$ ). ${ }^{2}$ In the second crop season the clone CL $02-05$ was not used in the experiment. ${ }^{3 *}, * *$ and ns represent statistical difference at $5 \%, 1 \%$ of probability, and no significant difference, respectively. ${ }^{4} \mathrm{CV} 1$ and $\mathrm{CV} 2$ indicate the coefficient of variation of the plot and subplot, respectively.

crop season 2013/14 (Table 3).

In the crop seasons of 2013/14 and 2014/15 a higher percentage of DW in the marketable tuber of cultivar BRS Camila in relation to Ágata was observed, and in crop season 2013/14 the cultivar BRS Camila did not differ from clone CL 02-05 (Table 3). Plants responded in a negative linear way and did not respond to fertilizer doses on DW percentage in crop seasons 2013/14 and 2014/15, respectively.

The studied cultivars on the present study are majorly used for in natura consumption, market segment in which the tuber percentage of DW is less valued than on industrial consumption (Garcia et al., 2015). However, tubers from cultivar BRS Camila are more suitable for home frying, since they showed higher percentage of tubers DW in one of the studied crop seasons. In fact, other authors have also observed higher DW percentage in marketable tubers of cultivar BRS Camila (clone F63-01-06) in relation to Ágata on the three trials held in their study (Silva et al., 2015). Plants submitted to higher doses of NPK have their percentage of DW reduced, mainly due to nitrogen (Kawakami, 2015). Moreover, the increment of potassium dose may result in the accumulation of this element in the tuber, promoting the reduction of the osmotic potential and increment of water absorption, what results in the dilution of DW content of tubers (Pauletti \& Menarim, 2004). The increment of phosphorus dosage may also lead to a slight reduction on DW percentage on soils with low availability of this nutrient; what may be the result of a dilution effect since there is increment on yield (Fernandes et al., 2015).

The new genotypes CL 02-05 and BRS Camila responded in a way similar to cultivar Ágata to the fertilizer doses used in the present study.

\section{ACKNOWLEDGMENTS}

The authors thank the Agronomist Renê Martins Bandeira Filho for providing the land and for the phytosanitary care of the experiment of the first crop season, and to Embrapa for providing seed tubers from cultivar BRS Camila and clone CL 02-05 used in the experiment.

\section{REFERENCES}

AZEREDO, EH; LIMA, E; CASSINO, PCR. 2004. Impactos dos nutrientes $\mathrm{N}$ e $\mathrm{K}$ e de açúcares solúveis sobre populações de Diabrotica speciosa (Germar) (Coleoptera, Chrysomelidae) e Agrotis ipsilon (Hüfnagel) (Lepidoptera, Noctuidae) na cultura da batata, Solanum tuberosum L. (Solanaceae). Revista Brasileira de Entomologia 48: 105-113.

BANGEMANN, LW; SIELING, K; KAGE, H. 2014. The effect of nitrogen and late blight 
on crop growth, solar radiation interception and yield of two potato cultivars. Field Crops Research 155: 56-66.

BISOGNIN, DA; COSTA, LC; ANDRIOLO, JL; MULLER, DR; BANDINELLI, MG. 2008. Produtividade e qualidade de tubérculos de clones de batata. Ciência e Natura 30: 43-56.

CARMO, EL; PÁDUA, JG; DIAS, JPT; DUARTE, HSS; DUARTE FILHO, J; LEONEL, M; ZAMBOLIM, L. 2009. Desempenho de cultivares nacionais e estrangeiras de batata em duas condições ambientais do Sul do Estado de Minas Gerais. Revista Trópica-Ciências Agrárias e Biológicas 3: 18-24.

CHIEN, S; PROCHNOW, L; TU, S; SNYDER, C. 2011. Agronomic and environmental aspects of phosphate fertilizers varying in source and solubility: an update review. Nutrient Cycling in Agroecosystems 89: 229-255.

DELEO JPB. 2015. Como gerir a bataticultura com custos em alta e demanda em baixa? Hortifruti Brasil. 14: 8-21.

EMBRAPA. 2013. Centro Nacional de Pesquisa de Solos. Sistema brasileiro de classificação de solos. 3 ed. Brasília: Embrapa. 353p.

ESCHEMBACK, V; KAWAKAMI, J; MELO, PE. 2014. Produtividade e características comerciais de tubérculos de clones e cultivares comercias de batata. Ambiencia 10: 699-706.

FERNANDES, AM; SORATTO, RP; MORENO, LA; EVANGELISTA, RM. 2015. Qualidade de tubérculos frescos de cultivares de batata em função da nutrição fosfatada. Bragantia 74: 102-109.

FERNANDES, AM; SORATTO, RP; SILVA, BL. 2011. Extração e exportação de nutrientes em cultivares de batata: I - macronutrientes. Revista Brasileira de Ciência do Solo 35: 2039-2056.

GARCIA, ÉL; CARMO, EL; PÁDUA, JG; LEONEL, M. 2015 Potencialidade de processamento industrial de cultivares de batatas. Ciência Rural 45: 1742-1747.
KANG, W; FAN, M; MA, Z; SHI, X; ZHENG, H. 2014. Luxury absorption of potassium by potato plants. American Journal of Potato Research 91: 573-578.

KAWAKAMI, J. 2015. Redução da adubação e doses e parcelamento de nitrogênio no crescimento e produtividade de batata. Horticultura Brasileira 33: 168-173.

LABOSKI, CAM; KELLING, KA. 2007. Influence of fertilizer management and soil fertility on tuber specific gravity: a review. American Journal of Potato Research 84: 283-290.

PAULETTI, V.; MENARIM, E. 2004. Época de aplicação, fontes e doses de potássio na cultura da batata. Scientia Agraria 5: 15-50.

PEREIRA, AS; NAZARENO, NRX; SILVA, GO; BERTONCINI, O; CASTRO, CM; HIRANO, E; BORTOLETTO, AC; TREPTOW, RO; DUTRA, LF; LIMA, MF; GOMES, CB; KROLOW, ACR; MEDEIROS, CAB; CASTRO, LAS; SUINAGA, FA; LOPES, CA; MELO, PE. 2015a. BRSIPR Bel: Cultivar de batata para chips com tubérculos de boa aparência. Horticultura Brasileira 33: 135-139.

PEREIRA, AS; SILVA, GO; BORTOLETTO, AC; HIRANO, E; CASTRO, CM; AZEVEDO, FQ; NAZARENO, NRX; SOUZA, ZS. 2015b. Catálogo de cultivares de batata. Pelotas: Embrapa Clima Temperado. 48p.

PEREIRA, AS; BERTONCINI, O; SILVA, GO; CASTRO, CM; GOMES, CB; HIRANO, E; BORTOLETTO, AC; MELO, PE; MEDEIROS, CAB; TREPTOW, RO; DUTRA, LF; LOPES, CA; NAZARENO, NRX; LIMA, MF; CASTRO, LAS; KROLOW, ACR; SUINAGA, FA; REISSER JUNIOR, C. 2013. BRS Clara: cultivar de batata para mercado fresco, com resistência à requeima. Horticultura Brasileira 31: 664-66.

PINTO, CABP; TEIXEIRA, AL; NEDER, DG; ARAÚJO, RR; SOARES, ARO; RIBEIRO,
GHMR; LEPRE, AL. 2010. Potencial de clones elite de batata como novas cultivares para Minas Gerais. Horticultura Brasileira 28: 399-405.

QUEIROZ, LRM; KAWAKAMI, J; MULLER, MML; OLEARI, ICR; UMBURANAS, RC; ESCHEMBACK, V. 2013. Adubação NPK e tamanho da batata-semente no crescimento, produtividade e rentabilidade de plantas de batata. Horticultura Brasileira 31: 119-127.

SHRESTHA, RK; COOPERBAND, LR; MACGUIDWIN, AE. 2010. Strategies to reduce nitrate leaching into groundwater in potato grown in sandy soils: case study from North Central USA. American Journal of Potato Research 87: 229-244.

SILVA, GO; PEREIRA, AS; NAZARENO, NRX; PONIJALEKI, R. 2015. Desempenho de clones de elite de batata para caracteres agronômicos e de qualidade industrial. Revista Ceres 62: 71-77.

SILVA, GO; PEREIRA, AS; SUINAGA, FA; PONIJALEKI, R. 2014. Adubação nitrogenada no rendimento da cultivar de batata BRS Ana. Horticultura Brasileira 32: 107-110.

SILVA, GO; CASTRO, CM; TERRES, LR; ROHR, A; SUINAGA, FA; PEREIRA, AS. 2012. Desempenho agronômico de clones elite de batata. Horticultura Brasileira 30: 557-560.

SILVA, L; PINTO, C. 2005. Duration of the growth cycle and the yield potential of potato genotypes. Crop Breeding and Applied Biotechnology 5: 10-28.

SOIL SURVEY STAFF. 2014. Keys to Soil Taxonomy, 12 ed. Washington, DC: USDANatural Resources Conservation Service. 372p.

SORATTO, RP; FERNADES, AM; SOUZASCHLICK, DS. 2011. Extração e exportação de nutrientes em cultivares de batata: II micronutrientes. Revista Brasileira de Ciência do Solo 35: 2057-2071. 